\title{
The Physiology of the Eye
}

IN spite of the war, a considerable number of important papers on the physiology of the eye were published last year. Some of them emanate from the comparative calm of American laboratories; others are probably an aftermath of work done in the last months of peace.

S. R. Detwiler (Jl. of Exp. Zool., Vol. XX, p. 165, 1916) has investigated the effect of light on the retina of the tortoise and lizard. The former possesses twin cones scattered amongst the ordinary cones, but has no rods. He found that the cones contract and the pigment migrates under the stimulus of light or electricity, and that the responses are not abolished by dividing the optic nerve. L. B. Arey (Jl. of Compar. Neurol., Philadelphia, Vol. XXVI, pp. 121, 213, $359,429,1916)$ has published a series of papers dealing with the same subject :- the movements of the visual cells and retinal pigment of the lower vertebrates (amphibia and fishes ; effects of temperature, ether, carbon dioxide, etc.) ; the function of the efferent fibres in the optic nerves of fishes; the influence of light and temperature on the migration of the retinal pigment in Planorbis trivolvis; changes in the rod visual cells of the frog due to the action of light. W. E. Burge (Amer. Jl. of Physiol., Vol. XXXIX, p. 335, 1916) discusses the mode of action of ultra-violet radiation on living cells, especially the eye. According to him a considerable rôle is played by the saline constituents.

Professor Hess has long been engaged upon an investigation of the visual sensations of lower animals (Vergleichende Physiologie des Gesichtsinnes, Jena, 1912). Briefly stated, his earlier conclusions were that mammals have the same spectral limits as man; that they have a similar capacity for dark adaptation; and that their luminosity curves are similar. That diurnal birds see the spectrum shortened towards the violet end, much as it would be seen by the human eye through a reddish-yellow glass; that the shortening is similar but rather less for nocturnal birds; that both types possess a power of dark adaptation the same as or very similar to that of man. That the vision of reptiles nearly resembles that of birds, and that they possess a high degree of dark adaptation. That amphibia appear to have similar vision to man. That fish have the visual perceptions of the totally colour-blind in man. Hess has now published an investigation of the light-sense in bees (Pflüger's Arch. f. d. gesamt. Physiol., Vol. CLXIII, p. 289, 1916), from which he concludes that they also are totally colour-blind. Hess's earlier results have been adversely criticised by Bauer, v. Fritsch, and France, and his recent results on bees by v. Buttle-Reepen (Mïnch. med. Woch., 1916, pp. 63, 789). H. Weve (Ned. Tijdschr. voor Geneeskunde, 1916, p. 
193) has used Hess's methods on the larvæ of Calliphora erythrocephala (Blowfly), and finds that they are totally colour-blind.

Professor C. S. Sherrington has devised a simple apparatus for demonstrating the Listing-Donders Law ( $J l$. of Physiol., Vol. L, p. 46, 1916).

J. W. Nordensson (Svenska Läkaresällskapets Handlingar, Vol. XLII, p. 1126, 1916) returns to the perennial question of the form of the. lens surfaces during accommodation, and finds that during a change of 5 or $6 \mathrm{D}$. the curvatures of the two surfaces are increased at the periphery as well as at the centre. The curvature of the centre is greater than that of the periphery both at rest and during accommodation. His results thus negative Tscherning's theory and support that of Helmholtz.

Percy W. Cobb has already published two excellent papers on the effect on foveal vision of bright surroundings (P. W. Cobb and L. R. Geissler, Psychol. Rev., Vol. XX., p. 425, 1913 ; P. W. Cobb, Psychol. Rev., Vol. XXI, p. 23, 1914). He now contributes a third (Jl. of Exp. Psychol., Vol. I, p. 417, 1916).

The war has brought into prominence many problems relating to the visibility of objects under various atmospheric conditions. One such problem deals with the perception of flashes of light of brief duration. It has already attracted attention in times of peace, for upon it depends the efficiency of lighthouse flashlights and so on. McDougall's investigations on recurrent vision (Brit. Jl. of Psychol., Vol. I. p. 78, 1904) led him to the conclusion that the dimmest light visible to the peripheral retina of the dark-adapted eye, i.e., the dimmest light perceptible under the most favourable circumstances, must be allowed to act for a period of not less than one-fifth of a second in order to be perceptible. A. Blondel approaches the subject from the point of view of the physicist. He has recently discussed (Comptes Rendus, Vol. CLXII, p. 587, 1916) the perception-limit of luminous signals produced by revolving beams of low divergence, and described an apparatus allowing comparison of brief light-flashes giving the same quantity of illumination in different times. In another paper (A. Blondel and J. Rey, Comptes Rendus, Vol. CLXII, p. 861, 1916) he discusses the comparison from the point of view of carrying range of brief lightsignals produced in a revolving apparatus by light sources allowing different durations of impression upon the eye, and the conditions determining the highest effectiveness of the light-flux employed.

\section{Colour Vision}

The work of H. E. Ives on flicker photometry reaches a very high standard. His studies in the photometry of lights of different 